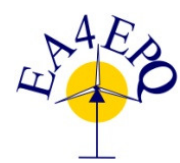

International Conference on Renewable Energies and Power Quality (ICREPQ'16)

Madrid (Spain), $4^{\text {th }}$ to $6^{\text {th }}$ May, 2016

Renewable Energy and OPoure Qualily. Journal (RE\&PQJ)

ISSN 2172-038 X, No.14 May 2016

\title{
Net zero emissions for a seminar room in the University of Balearic Islands
}

\author{
A. Moià-Pol ${ }^{1}$, Beatriz Rosselló-Batle ${ }^{1}$, C. Carmona ${ }^{2}$ and B. Alorda ${ }^{2}$ \\ ${ }^{1}$ Department of Physics-Mechanical Engineer Area- Engineering Group of Energy Management \\ ${ }^{2}$ Department of Physics - Architectonic construction and building engineering group \\ Balearic Island's University (U.I.B.) \\ Carretera Valldemossa km 7,5, 07122 Palma de Mallorca (Spain) \\ Phone/Fax number:+0034971171374, e-mail: andreu.moia@uib.es, beatriz.rossello@uib.es
}

\begin{abstract}
In this study the energy retrofit of a seminar room in the University of Balearic Islands was evaluated. This room was built in the late 80 s and it was equipped with halogen lights and Compact Fluorescent Light Bulbs (CFLs). The climate system consisted of an air to air heat pump system. Development of modern net zero-energy buildings (NZEB) became possible with the combination of solar thermal, photovoltaic and geothermal energy systems. This kind of combination was used to improve the energy efficiency of the room evaluated in this paper, together with the installation of an innovative radiant heating and cooling ceiling system. Although renewable energy can cover all the annual energy consumption, a small fraction of auxiliary energy is provided by heat pump systems (HP).. Solar heating combined with geothermal systems for buildings have been designed to achieve different values of the fraction of a primary energy saving using Flat Plate Collectors (FPC) for Solar Thermal (ST) and other supply energies like solar photovoltaic (PV) or wind technology, and having the higher efficiency of the system with net zero energy.
\end{abstract}

\section{Key words}

Solar Thermal, Heat Pump, Photovoltaic, geothermal, combisystems.

\section{Introduction}

Article 9 of Directive 2010/31/EU of 19 May 2010 on energy performance of buildings establishes that "Member States shall ensure that by 31 December 2018 all new buildings occupied and owned by public authorities are nearly zero-energy buildings" [1]. It requires a new building concept and a big effort by the construction sector, including engineers, architects and ESCO. This new type of buildings will be obtained reducing the energy demand, using renewable energies and more efficient systems.

Radiant cooling systems require usually less energy consumption than conventional cooling systems. Radiant ceiling systems are ideal for cooling in existing buildings, because the cost of the retrofit. Recently, reductions in electric PV costs and mature technology of heat pumps have provided a new model: solar-electric assisted heat pump [2]. This system comes with fewer drawbacks than solar thermal energy, a smaller price tag for residential applications. Nevertheless, the best system would be a combination of both. Development of modern net zeroenergy buildings (NZEB) became possible not only through the progress made in new renewable energy and construction technologies and techniques, but it has also been significantly improved by the combination of all the techniques and advanced combisystems.

Some research groups are studying the best combination to archive this goal. According to thermal necessities and weather conditions, the design needs to be adapted in each area [3]. Radiant cooling (floor or ceiling) is not so often used but with the appearance of high efficiency aerothermal systems they have started to be installed with more frequency, though new constructions cover all thermal necessities (hot water, heating and cooling) with one system, especially at southern countries [4]. The building considered in this study, was previously the first Rectorate of the University, and the seminar room was built in the late 80 s.

\section{New Design}

Firstly, the seminar room had an old Air-Air Heat Pump, Roca-York, with fibber ducts and light ventilation, according to the standards of the 80 's. See Figure 1.

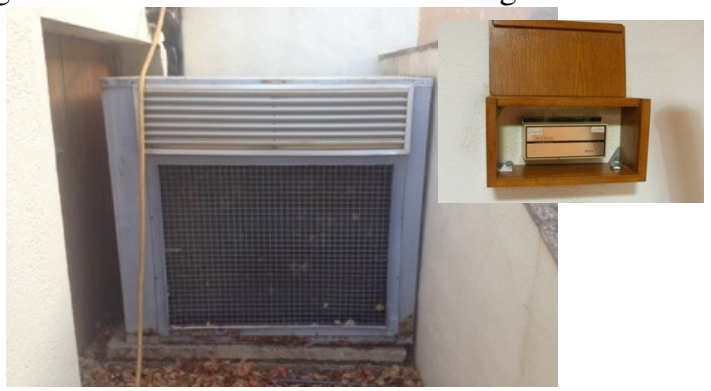

Fig. 1. Old Heat Pump and control system

The old lights with halogens, CFLs and incandesce had an electric power of $2037 \mathrm{~W}$, with a very heavy transformer $(230 \mathrm{~V}$ to $12 \mathrm{~V})$. The new light system installed in the room has a power of $738 \mathrm{~W}$, and are lineal LEDs. Using the Spanish official software (CALENER) [5] the room was simulated and different technology and strategies to 
reduce the energy consumption were assessed. $\mathrm{CO}_{2}$ emissions obtained for the room showed the worst letter in the Spanish label $(\mathrm{G})$, with an indicator for global emissions of $118,39 \mathrm{kgCO} / \mathrm{m}^{2}$. An F label was obtained for heating and cooling,, with a maximum consumption of 72,48 and $8,36 \mathrm{kWh} / \mathrm{m}^{2}$, respectively, and maximum emissions of 80,89 and $8,07 \mathrm{kgCO}_{2} / \mathrm{m}^{2}$.

The old system in this seminar room was replaced by an innovative radiant heating and cooling ceiling system composed by:

-Calcium silicate insulation boards $(2-3 \mathrm{~cm})$, highly higroscopic, used as thermal insulation and as support of the rest of the system elements (dry bulk density: 200-350 $\mathrm{kg} / \mathrm{m}^{3}$; thermal conductivity $<0,06 \mathrm{~W} / \mathrm{m} \mathrm{K}$ ). These plaques allow water absorption at temperatures below the dew point. When the system is not operating, they release the stored water. It has been demonstrated that this material can absorb several times its own weight in water.

-A mesh of capillary tubes made of polypropylene, which allows thermal diffusion at a low temperature over a large area.

-A clay finish is used to cover the ensemble.

An embodied energy assessment is not the goal of this study. Nevertheless, in Table I, values for the embodied energy and $\mathrm{CO}_{2}$ emissions for the materials included in the described ensemble are shown. They are observed to be lower values in comparison with other materials used in buildings.

Table I. - Approximate embodied energy and $\mathrm{CO}_{2}$ emissions for the described ensemble [6].

\begin{tabular}{|c|c|c|}
\hline & $\mathbf{E E}\left(\mathbf{k W h} / \mathbf{m}^{2}\right)$ & $\mathbf{E C O}_{\mathbf{2}}\left(\mathbf{k g} / \mathbf{m}^{\mathbf{2}}\right)$ \\
\hline Expanded clay concrete & 61,6 & 18,1 \\
\hline Calcium silicate plaques & 3,9 & 1,3 \\
\hline & $\mathbf{E E}(\mathbf{k W h} / \mathbf{m})$ & $\mathbf{E C O}_{\mathbf{2}}(\mathrm{kg} / \mathbf{m})$ \\
\hline Polypropylene tubes & 3,3 & 1,7 \\
\hline
\end{tabular}

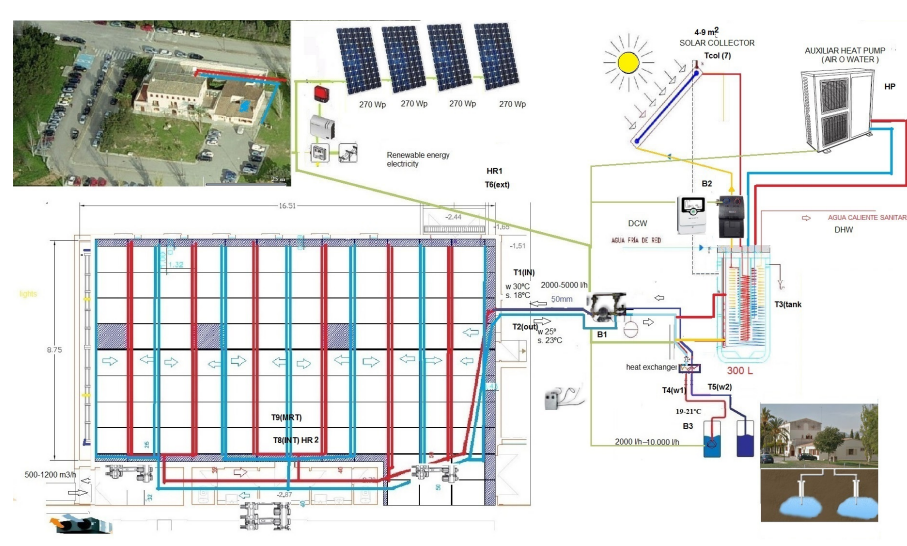

Fig. 2. Design of the system.

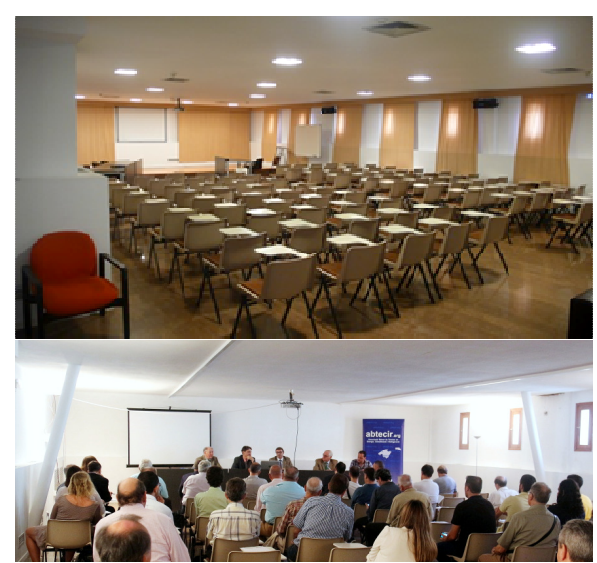

Fig. 3. View of the seminar room, before and after the retrofit.

In summer a geo-cooling system is utilised, making use of an existing and very old well near the building, with a constant temperature of water of $17^{\circ} \mathrm{C}$ during all the year, enough for the radiant system. In winter solar collectors provide water with a temperature from $25^{\circ} \mathrm{C}$ to $35^{\circ} \mathrm{C}$, with a high efficiency. This system doesn't need any auxiliary dehumidifier system, because of the calcium silicate hygroscopic panels. Other radiant systems need to be switch off or auxiliary equipments when they have condensation problems. This new system avoids any extra consumption in extreme conditions. See Figures 2 and 3.

A new efficient air to water heat pump has been installed, this is used as auxiliary system in extreme days. The energy savings and consumption using this new system are shown in Table II.

Table II. - Energy Consumption and $\mathrm{CO}_{2}$ emissions

\begin{tabular}{|c|c|c|}
\hline & Before & New system \\
\hline Electricity kWh/year & 3507 & 330 \\
\hline Kg CO2/year & 1708 & 0 \\
\hline PV prod. kWh/year & 0 & 423 \\
\hline Solar Thermal used & 0 & 748 \\
\hline
\end{tabular}

\section{Simulated and real Results}

The system was completely installed in the seminar room in September 2015. As indicated previously, it is composed by a new radiant ceiling system (see Figure 4), a well (geo-cooling system), Flat Plate Collectors, AirWater Heat Pump, Storage Tank of 300L [7], Photovoltaics panels polycrystalline (PV) [8] with an inverter for the grid, a ventilation system (with heat recovery), the control and data logger systems.

The initial results are very promising and would validate the simulated results, obtained using various software tools (TRANSOL, GREENIUS, CALENER). These results will be validated during one year of collecting data. The radiant system reduce working temperatures of the system $\left(17-22^{\circ} \mathrm{C}\right.$ at summer and $28-33^{\circ} \mathrm{C}$ at winter) and do not need any fan to transfer the heat, if we compare this with the fan coil, that they need to work $\left(7-12^{\circ} \mathrm{C}\right.$ at 
summer and $40-45^{\circ} \mathrm{C}$ ), only this fact makes increase the efficiency of the heat pump a $30 \%$.

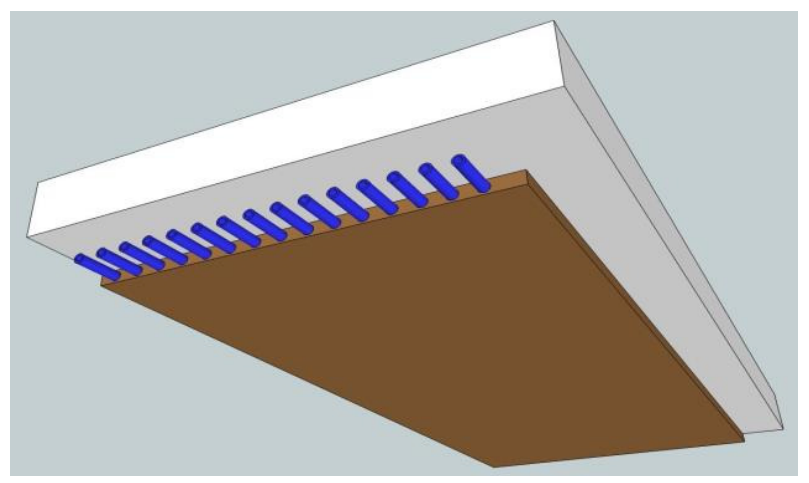

Fig. 4. View of the hygroscopic radiant panel [7]

The heat transfer is very uniform in all the room, if the hydraulic circuits are well regulated, each panel has a capillary pipe every $2 \mathrm{~cm}$, with a total of 50 capillaries. Each capillary have a diameter of $3.4 \times 0.55 \mathrm{~mm}$, round distribution tube $20 \times 2.0 \mathrm{~mm}$. The new system uses renewable energies during all the year, and a small quantity of electricity needed for pumps and auxiliary systems. There are more components in the system but a good control and design allows a high reduction of the electric consumption, compared with the old system. As can be seen in Table III, the installed power of the new system is $50 \%$ lower than before, including the chiller, only necessary for emergency days. In these case the reduction it's the $85 \%$ at summer and $95 \%$ at winter. See Figure 4.

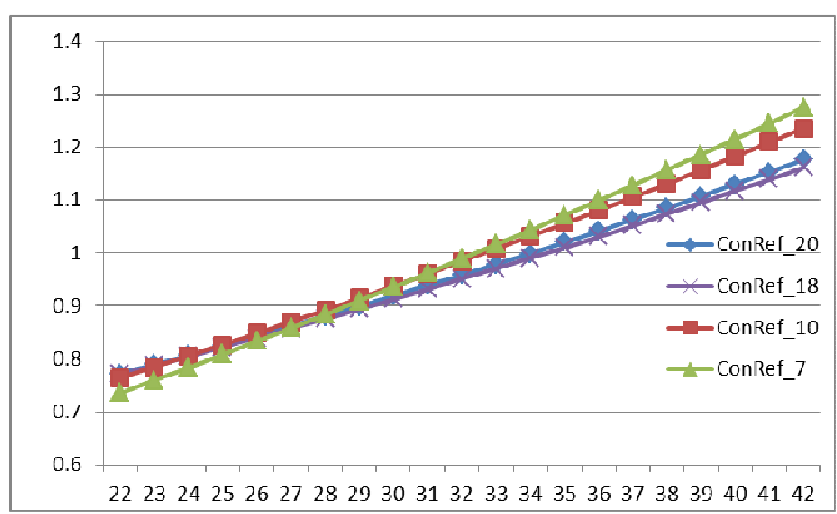

Fig. 3. Unitary electric consumption from a heat pump in different condensation/evaporation temperatures, using Calener simulation [5].

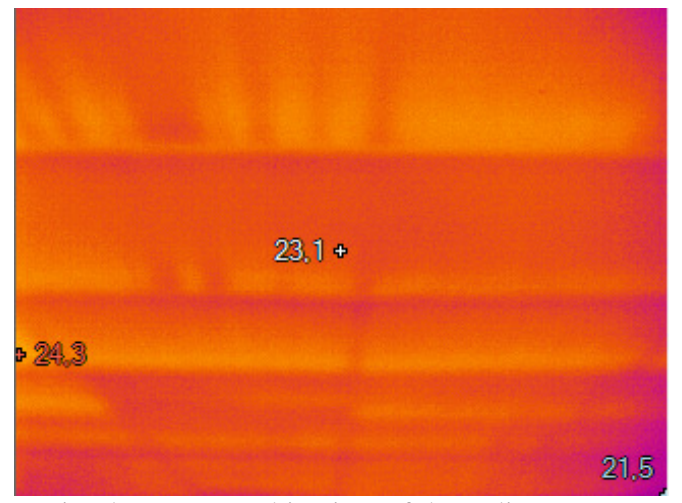

Fig. 5. Termographic view of the radiant system
A new control system will be installed, with data logger and a webserver.

Table III. - Electrical power

\begin{tabular}{|c|c|c|c|c|}
\hline & \multicolumn{2}{|c|}{ Before } & \multicolumn{2}{c|}{ New system } \\
\hline & Winter & Summer & Winter & Summer \\
\hline Heat Pump/Chiller* & 9.3 & 10.3 & 4 & 3.61 \\
\hline Pump from the well & & & & 1.2 \\
\hline Solar Pump & & & 0.04 & \\
\hline Secondary Pump & & & 0.06 & 0.06 \\
\hline Dehumification & 0.3 & 0.3 & & \\
\hline Ventilation & 0.3 & 0.3 & 0.4 & 0.4 \\
\hline Total & $\mathbf{9 . 9}$ & $\mathbf{1 0 . 9}$ & $\mathbf{4 . 5}$ & $\mathbf{5 . 2 7}$ \\
\hline Total without chiller & $\mathbf{9 . 9}$ & $\mathbf{1 0 . 9}$ & $\mathbf{0 . 5}$ & $\mathbf{1 . 6 6}$ \\
\hline
\end{tabular}

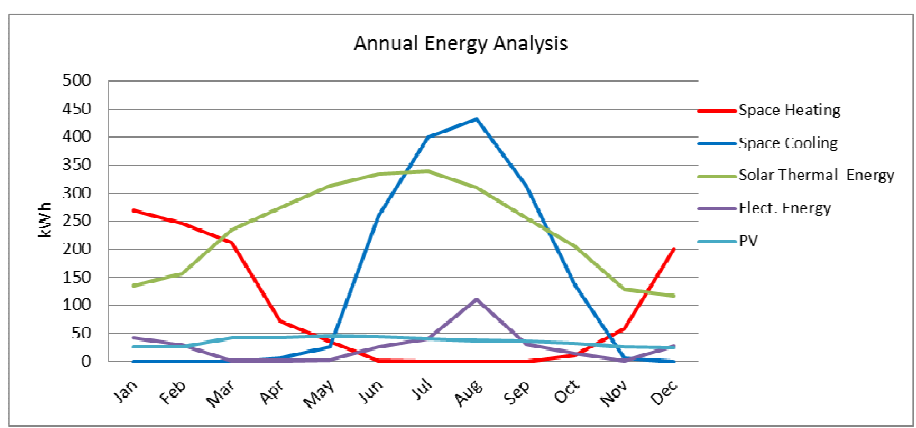

Fig. 4. Annual Energy Consumption and Mix of Renewable sources

\section{Conclusion and future analysis}

With the new system evaluated in this study between 85 $95 \%$ of the installed power has been reduced. The reduction of the energy consumption will be $90 \%$.

Radiant cooling energy systems allow savings near 30\% compared to conventional ones (Fan coils or split) and they can work with optimal temperatures for geothermal and solar thermal energy.

Using the properly mix of renewable energies the evaluated seminar room will be a real NZEB.

The electricity production has higher emissions in the Balearic Islands than in the mainland's, over double, due to the use of coal in a big percentage, about $840 \mathrm{gr} / \mathrm{kWh}$. To reduce the impact of the small quantity of electricity consumed, a PV system will be installed, and a Net metering contract will be made with the electrical company to compensate the electric consumption. An excess will be produced in summer with and a lower production in winter..

A small wind turbine of $500 \mathrm{~W}$ will be as well installed, as a demonstrative system, even the expected working hours would be less than $10 \%$ of the equivalent time. The test would be useful for future installations in other locations with more wind and less solar radiation. From the simulated results it is clear that in summer solar thermal collectors have an over production. A seasonal storage will be dimensioned according to the results obtained of the real test. 


\section{Acknowledgement}

The authors acknowledge the financial support from Hippokrates GmbH and Programa Pont "La Caixa" per a grups de recerca de la UIB.

\section{References}

[1] Recast, E. P. B. D. (2010). Directive 2010/31. EU of the European Parliament and of the Council of, 19.

[2] http://www.iea-shc.org/task44

[3] Andreu Moià Pol, Víctor Martínez Moll, Ramon Pujol Nadal and Rashid Nazmitdinov. Study Case of Solar Thermal and Photovoltaic Heat Pump System for Different Weather Conditions. Proceedings of the Eurosun 2014, Aix-les-Bains, France.

[4] Andreu Moià Pol, Víctor Martínez Moll, Miquel Alomar Barceló, Ramon Pujol Nadal. Solar and heat pump systems. An analysis of several combinations in Mediterranean areas. Proceedings of the Eurosun 2012, Rijeka, Croatia.

[5] http://www.codigotecnico.org/ Spanish Technical Building Code and http://www.idae.es

[6] ITeC. Bedec Database. Available at: http://itec.es/nouBedec.e/bedec.aspx

[7] Glen Dimplex Deutschland GmbH, ROTEX Heating Systems $\mathrm{GmbH}$ and Computer simulations by the Institute for Building Energetics at the University of Stuttgart.

[8] Martin A. Green, Keith Emery, Yoshihiro Hishikawa, Wilhelm Warta and Ewan D. Dunlop. Solar cell efficiency tables (Version 45). Volume 23, Issue 1, pages 1-9, January 2015. Progress in Photovoltaics.

[9] http://www.hippokrates-clima.com/ 